\title{
Physical-chemical characterization of yellow passion fruit produced in different cultivation systems
}

\author{
Naama Jessica de Assis Melo*, Andréia Mitsa Paiva Negreiros, José Dárcio Abrantes Sarmento, \\ Patrícia Lígia Dantas de Morais, Rui Sales Júnior
}

Universidade Federal Rural do Semi-Árido - UFERSA, Mossoró-RN, Brazil

\section{A B S T R A C T}

\begin{abstract}
Grafting is widely used to provide resistance to pests and diseases in yellow passion fruit, such as fusariosis, caused by the fungus Fusarium oxysporum f. sp. passiflorae (FOP). However, this practice may generate some changes in the postharvest characteristics of the fruits. The objective of this work was to verify the postharvest quality of fruits of $P$. edulis collected mature and ripe in three areas with different forms of cultivation (conventional without grafting, conventional with grafting and organic with grafting). The experiment was installed in a completely randomized design, in a $3 \times 2$ factorial scheme, with five replicates of four fruits each. The first factor was the different cultivation systems and the second factor was the maturity stage. The fruits were harvested, selected and submitted to physical, physical-chemical and chemical analysis, bioactive compounds and antioxidant activity. Fruit and pulp weight, longitudinal and transverse length and firmness were superior in fruits from conventional without grafting system, however fruit yield was inferior for this system. Soluble solids, $\mathrm{pH}$, reducing sugars and total soluble sugars were superior in fruits from organic with grafting system. Bioactive compounds and antioxidant activity were improved in conventional without grafting system fruits.
\end{abstract}

Keywords: Bioactive compounds; Grafting; Passiflora edulis; Postharvest

\section{INTRODUCTION}

The genus Passiflora belongs to Passifloraceae family. More than 500 species pertain to this family and are distributed in regions of tropical and subtropical climate of the world. Despite the differences, several species are popularly named passion fruit (Cervi, 2006). The species Passiflora edulis Sims, known as passion fruit, is the most produced and marketed (IBGE, 2017). Especially due to its higher acidity and pulp yield, its cultivation is primarily focusing on the juice and pulp industry (Jesus et al., 2018).

Studies reveal that this fruit can be an excellent source of essential nutrients for life as carbohydrates, vitamins, and minerals. Passion fruit has also a high content in nutraceuticals, as phenolic acids, where the majoritarian compounds of this group are flavonoids and anthocyanins. Carotenoids and $\beta$-carotene are also found as the main components, and consequently provitamin A activity is increased. Biological activities in the health, protective effect against degenerative and chronic diseases can be related with these nutraceutical compounds, besides the fact that can act as mutagenesis and carcinogenesis inhibitors. Also, antiviral, antiallergic and anti-inflammatory activities have been associated with these compounds (Morais et al., 2016; González-Gallego et al., 2014). However, during the long shipping or air transportation periods of times, fruits undergo changes by accelerated ripening. They lose organoleptic quality generating economic losses for exporting companies up to $15 \%$ of the total volume shipped. Fruits are harvested immature and arrive at the consumer fully mature, but with differences in their physicochemical composition (Jiménez et al., 2011).

Grafting is widely used in fruit culture and in other perennial species to propagate superior genotypes, to control plant size, reduce juvenile period, improve the adaptation to adverse soil conditions and to provide resistance to pests and diseases (Atucha et al., 2014; Salazar et al., 2015). One of the main diseases that grafting aims to reduce the incidence is fusariosis, also known as fusarium wilt, caused by the fungus Fusarium oxysporum $\mathrm{f}$. sp. passiflorae

\footnotetext{
*Corresponding author:

Naama Jessica de Assis Melo, Center of Agrarian Sciences, Department of Agricultural and Forestry Sciences, Universidade Federal Rural do Semi-Árido - UFERSA, Mossoró-RN, Brazil. E-mail: naama.melo@ufersa.edu.br
} 
(FOP). The symptoms start with branch yellowing and wilt (Fischer et al., 2010). Due it is a vascular disease, the chemical control of fusariosis is not efficient. In this case, preventive measures of cultural control are used, besides the use of grafted seedlings on rootstocks of wild species with potencial for resistance (Cavichioli et al., 2009).

In addition to grafting, the growing demand for healthy food, valuing biological diversity and without the use of chemical fertilizers and pesticides, is a trend that favors the creation of new opportunities, especially for small farmers. The system of organic cultivation of yellow passion fruit has been adopted by producers, however, there is a lack of scientific information on the organic cultivation of the crop (Fischer et al., 2007). Macoris et al. (2011) studying yellow passion fruits from organic and conventional cultivation, found that fruits from organic cultivation obtained lower content of total soluble solids, reducing sugars and total soluble sugars than conventional cultivation fruits. Bioactive compounds can also be affected due to the cultivation method. Pertuzatti et al. (2015) found that total carotenoids and $\beta$-carotene were higher in passion fruit from conventional cultivation, unlike vitamin $\mathrm{C}$ content, which was higher in organic fruit.

Silva et al. (2013) reported, in Passiffora crops, tolerance of some wild species such as $P$. suberosa L., P. alata Curtis and P. cincinnata Mast. to premature death of the plants (Fusarium spp.). Thus, there have been several studies evaluating the effect of rootstock and graft type on fruit quality of yellow passion fruit. Cavichioli et al. (2011a) found that the rootstocks studied did not influence the content of soluble solids (SS), titratable acidity (TA) and the SS/TA ratios. Similarly, the grafting method did not affect the diameter, length, weight of the fresh fruit, weight and thickness of the peel, and juice yield. Salazar et al. (2015) verified that fruits from ungrafted plants obtained higher values of fresh mass, diameter, peel mass, soluble solids and vitamin C. However, scarce information is available on the behavior of bioactive compounds in fruits from grafted plants and in different cropping systems (conventional and organic).

Thus, the objective of this work was to verify the physical, physical-chemical and chemical postharvest quality and antioxidant capacity of fruits of $P$. edulis collected in two maturation stages in three areas with different forms of cultivation (conventional without grafting, conventional with grafting and organic with grafting).

\section{MATERIALS AND METHODS}

\section{Sample preparation}

Fruits of yellow passion fruit, $P$. edulis, were derived from three commercial orchards, located in the cities of Jaguaruana, Ceará (4 ${ }^{\circ} 58^{\prime} 00.6^{\prime \prime}$ S and 37 47'10.3”W), Coronel Ezequiel, Rio Grande do Norte ( $06^{\circ} 23^{\prime} 30.26^{\prime \prime S}$ and $\left.36^{\circ} 10^{\prime} 38.26^{\prime \prime} \mathrm{O}\right)$ and in rural community of

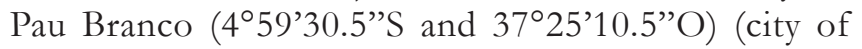
Mossoró, Rio Grande do Norte), cultivated in an organic system with grafting, conventional without grafting and conventional with grafting, respectively, brazilian semiarid. In farms that used grafting, Passiffora cincinnata was used as a rootstock. The organic cultivation system used as biofertilizer legume cocktail and animal manure. In the conventional systems, pesticides were applied when needed and inorganic fertilizers were used following usual recommendations.

The fruits were harvested between 2016 and 2017. The climate of the region, according to the Köppen classification, is "BSw", dry semiarid with low altitude and latitude, average air temperature of $26.7^{\circ} \mathrm{C}$ and relative humidity of $68.9 \%$. The average annual precipitation is about $750 \mathrm{~mm}$, with a rainy period between February and June and low probability of rains between August and December. In general, they present shallow, rocky, but fertile soils (Alvares et al., 2014).

The fruits were harvested manually, in the morning, in two maturation stages: breaker/turning yellow (physiologically mature) and complete yellow colored (ripe), according to company rules. In the laboratory, the fruits went through a process of selection, being discarded those that presented damages by cuts, abrasions, attacks of insects or animals and, later, they were cleaned with the aid of a damp cloth.

The fruits were submitted to quality physical evaluations and then pulp containing the seeds was separated from the peel (epicarp) after a cross section in the fruit, manually with the help of stainless steel knives. The pulp fraction (mesocarp) was separated from the seeds with the aid of plastic sieves and stored in plastic pots and stored in a freezer at $-23^{\circ} \mathrm{C}$ for further analysis.

The experiment was installed in a completely randomized design, in a $3 \times 2$ factorial scheme, with five replicates of four fruits each, on a bench with fruits brought from the field. The first factor was the different cultivation systems (conventional cultivation without grafting, organic cultivation with grafting practice and conventional cultivation with grafting practice) and the second factor was the maturity stage [breaker/turning yellow (physiologically mature) and complete yellow colored (ripe)].

\section{Physical characteristics}

For the physical analyzes of quality, the fruits were divided into five replicates of four fruits each, totaling 20 samples, for each stage of maturation of each cultivation system. 
In total, 60 yellow passion fruits were used at mature stage and 60 fruits at ripe stage (Fig. 1).

Longitudinal length $(\mathrm{mm})$, transverse length $(\mathrm{mm})$ and peel thickness $(\mathrm{mm})$ were determined using a digital pachometer (Lotus plus); fruit weight $(\mathrm{g})$ and pulp weight $(\mathrm{g})$ using an analytical balance (Bel Engineering); and pulp yield ( $\%$ ) obtained by the difference between fruit weight and pulp weight.

The color of the peel and the pulp was expressed in Luminosity (brightness, clarity or reflectance), Chromaticity (saturation or intensity of color) and ${ }^{\circ} \mathrm{H}$ (hue angle tonality) (Commission Internacionale de L'Eclaraige) (Minolta, 2007), using a digital benchtop colorimeter $\left(\right.$ CR-140, Minolta ${ }^{\circledR}$ ). Readings in the peel were determined randomly at two equidistant points in the equatorial region, considering the average between them, and for the color of the pulp the readings were performed after the separation of the seeds in petri dishes.

The firmness of the fruit was determined using the Texture Analyzer $^{\circledR}$, model TA.XTExpress / TA.XTicon (Stable

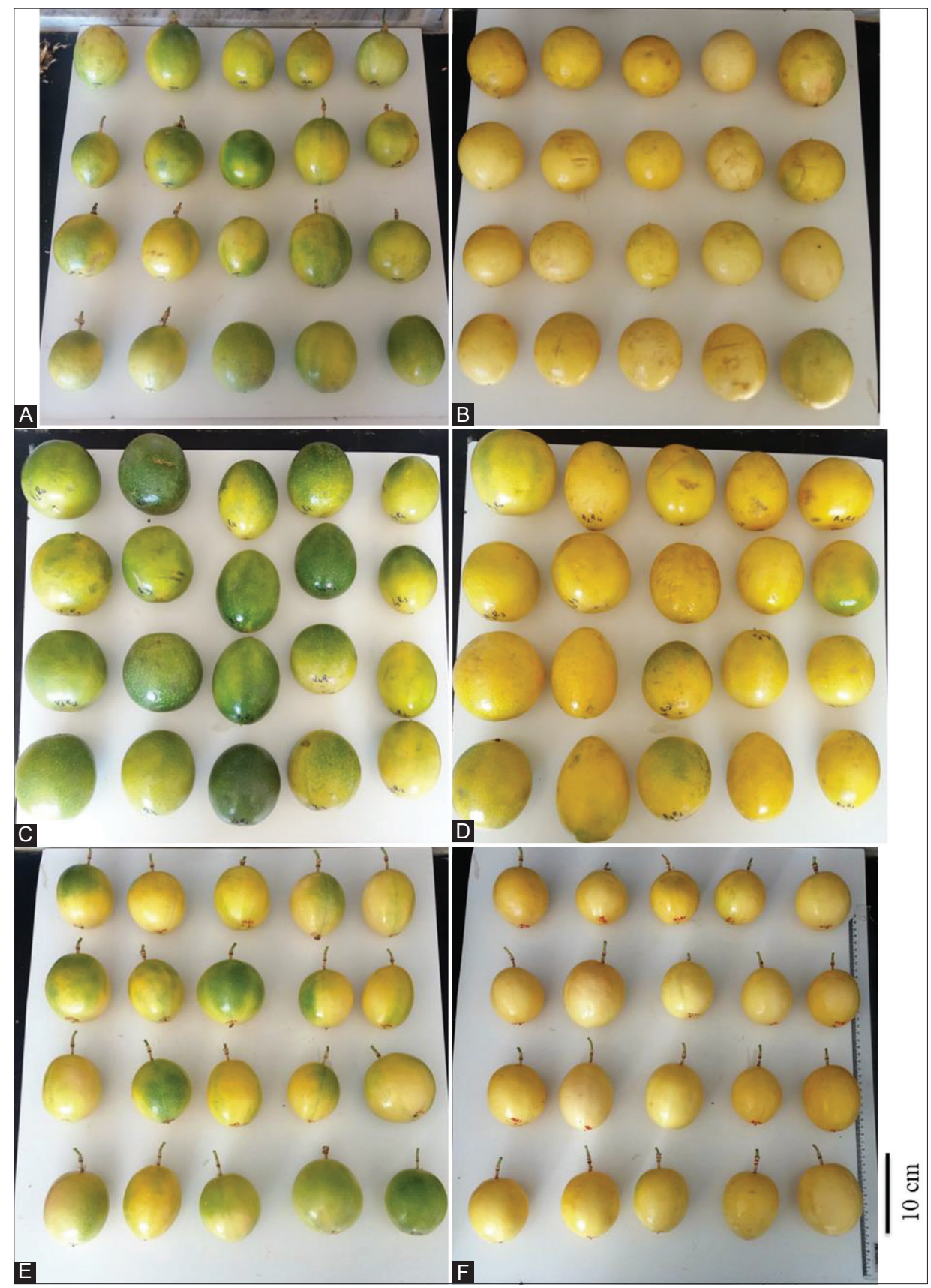

Fig 1. Fruits collected in the localities of Jaguaruana ( $A$ and $B)$, Coronel Ezequiel ( $C$ and $D)$ and Pau Branco $(E$ and $F)$, in two maturation stages: mature $(A, C$ and $E)$ and ripe $(B, D$ and $F)$. 
Micro Systems Ltd., Surrey, England) with a $10 \mathrm{~kg}$ load cell. The cylindrical probe of stainless steel with a diameter of $5 \mathrm{~mm}$ (model $\mathrm{P} / 5$ ) was used. The pre-test, test and post-test speeds were $2 \mathrm{~mm} / \mathrm{s}, 2 \mathrm{~mm} / \mathrm{s}$ and $10 \mathrm{~mm} / \mathrm{s}$, respectively, and penetration distance of $10 \mathrm{~mm}$. Two equidistant measurements were performed, one in each equatorial region of the fruit, and considered the average between them. The results were expressed in Newton $(\mathrm{N})$.

\section{Physical-chemical and chemical characteristics}

The physical-chemical and chemical analyzes were performed from five replicates of four fruits each.

The hydrogenation potential $(\mathrm{pH})$ was determined using a direct reading potentiometer (Model mPA-210 Tecnal $^{\circledR}$, Brazil). The data were expressed in real $\mathrm{pH}$ values (AOAC, 2002).

The titratable acidity (TA) was determined by volumetric procedure, according to Instituto Adolfo Lutz (2005), using an automatic titrator (Titrette ${ }^{\circledR}$ model Class A Precision by BRAND, USA), and results were expressed as $\mathrm{mg}$ of citric $\mathrm{acid} / 100 \mathrm{~g}$ of pulp.

Total soluble solids were determined with pulp juice in a digital refractometer (model PR-100, Pallete, Atago Co, LTD, Japan) (AOAC, 2002). The results were expressed as percentage (\%); and the soluble solids/titratable acidity ratio (SS/TA) was determined by the ratio between the soluble solids values and the titratable acidity.

Total soluble sugars (TSS) were determined by the method of Antrona (9,10-dihydro-9-oxaanthracene) (Vetec, Brazil), according to Yemn and Willis (1954). Reducing sugars (RS) by the DNS (DNS, Vetec, Brazil) method was performed according to Miller (1959). The results for these analysis were expressed as percentage (\%).

\section{Bioactive compounds and total antioxidant activity (TAA)}

Vitamin $\mathrm{C}$ was determined according to the methodology proposed by Strohecker and Henning (1967), the results being expressed as $\mathrm{mg}$ ascorbic acid/100 $\mathrm{g}$ fresh weight (FW).

Yellow flavonoids were determined according to Francis (1982). The readings were performed in a spectrophotometer (UV-1600 model, Pró-Análise ${ }^{\circledR}$, Brazil) with wavelength of $374 \mathrm{~nm}$ with absorption coefficient of $76.6 \mathrm{~mol} / \mathrm{cm}$, the results being expressed in $\mathrm{mg} / 100 \mathrm{~g}$ FW.

The procedure for the determination of total carotenoids was performed according to Higby (1962). The reading was carried out in a spectrophotometer at $450 \mathrm{~nm}$ and the results expressed in $\mathrm{mg} / 100 \mathrm{~g}$. $\beta$-carotene was performed according to the methodology of Nagata and Yamashito (1992). The content of the analysis was collected for spectrophotometer reading at four absorbances: 663, 645, 505 and 453 . The results were expressed as $\mathrm{mg} / 100 \mathrm{~mL}$ juice.

\section{Extract for total extractable polyphenols (TEP) and total antioxidant capacity (TAA) by ABTS $^{\circ}+$ and DPPH methods}

The methodology was described by Larrauni et al. (1997), with modifications. $10 \mathrm{~g}$ of the samples were weighed into centrifuge tubes and $10 \mathrm{~mL}$ of the methanol-water extracting solution $(50: 50, \mathrm{v} / \mathrm{v})$ was added at room temperature for $1 \mathrm{~h}$. The tubes were centrifuged for $20 \mathrm{~min}$ at $10,000 \mathrm{rpm}$ and the supernatant recovered. $10 \mathrm{~mL}$ of a second acetone-water extracting solution (70:30, v / v) was added to the residue for $1 \mathrm{~h}$ at room temperature, and centrifuged. The two supernatants were mixed in a volumetric flask, and added to $25 \mathrm{ml}$ of distilled water. The extract was used to determine the content of total extractable polyphenols and antioxidant capacity by ABTS and DPPH method.

\section{Total extractable polyphenols (TEP)}

TEP were determined by colorimetric assay using the Folin-Ciocalteau reagent, according to the methodology described by Obanda and Owuor (1997). The readings were performed in a spectrophotometer at $700 \mathrm{~nm}$, using a standard curve of gallic acid 98\% (dosed at 0, 10, 20, 30, 40 and $50 \mu \mathrm{g}$ ). The results were expressed as gallic acid equivalents (GAE) $\mathrm{mg} / 100 \mathrm{~g} F W$.

\section{Total antioxidant activity (TAA) - ABTS assay* ${ }^{+}$}

TAA by the ABTS $^{\cdot+}$ method was determined using 2,2-azinobis-3-ethylbenzthiazoline-6-sulphonic acid radical cation (ABTS ${ }^{*+}$, Sigma) (Re et al., 1999). The ABTS ${ }^{\cdot+}$ radical was generated through the reaction of the $7 \mathrm{mM}$ ABTS solution with $140 \mathrm{mM}$ potassium persulfate, and leaving in the dark for $16 \mathrm{~h}$ at room temperature before use. A calibration curve with the synthetic antioxidant Trolox (6-hydroxy-2,5,7,8-tetramethylchroman-2-carboxylic acid, Sigma) at the concentration of 100 to $2000 \mu \mathrm{M}$ in ethanol was made and the results of the analysis were expressed in $\mu \mathrm{mol}$ of Trolox/g FW.

\section{TAA - DPPH assay}

The methodology for the determination of the antioxidant activity by the DPPH method was performed according to Sanchez-Moreno et al. (1998). In the dark, after $1 \mathrm{~h}$ and 10 $\mathrm{min}$, the readings were carried out in a spectrophotometer at $515 \mathrm{~nm}$. A calibration curve was performed with DPPH solutions in methyl alcohol varying the concentration from $10 \mu \mathrm{M}$ to $50 \mu \mathrm{M}$ and the results of the analysis were expressed in $g$ of fruit/g DPPH. 


\section{Statistical analysis}

Data were submitted to analysis of variance using the program SISVAR 5.6 (Ferreira, 2014) and Tukey's test at $5 \%$ probability for comparison of means.

\section{RESULTS AND DISCUSSION}

\section{Physical characteristics}

For the variables that presented interaction between the cultivation system and the maturation stage in the analysis of variance, the data were analyzed together. For those without interaction, the data were analyzed separately.

There was a significant effect for the interaction of cultivation system $\mathrm{x}$ maturation stage for all analyzes except for pulp weight, pulp yield, firmness and pulp luminosity and hue angle $(\mathrm{p}<0.05)$ (Tables 1 and 2$)$.

The fruits of yellow passion fruit at the mature stage used in the experiment had a mean weight ranging from 175.88 to $315.79 \mathrm{~g}$, whereas in the ripe stage the variation was from 138.08 to 333.77 g. Regarding to cultivation system, the fruits with the highest weight were those harvested from conventional cultivation system without grafting, in both maturation stages (Table 1), with an increase of $106.89 \%$ in the weight of these fruits as compared with those from conventional with grafting. However, pulp yield was inferior. Only the weight of the fruits of this cultivation system was within the market preference for fresh fruits, where they must have a fresh weight of more than $200 \mathrm{~g}$ (Aguiar et al., 2015). The differences observed between the weight of the fruits from grafting may have been due to the vigor of the plants, since they are materials of different species, as verified by Nogueira Filho et al. (2010), where plants grafted on $P$. gibertii presented lower vigor in the field, which may have influenced weight, longitudinal length and average diameter of the fruits. Fischer et al. (2007) analyzing yellow passion fruits in conventional and organic cultivation systems verified weights of 156.13 and $175.27 \mathrm{~g}$, respectively. Jesus et al. (2018) analyzing fruits of five different cultivars found a variation of 179 to 228 g. In this way, it is possible to observe that there is a great variation of fruit weight in the species $P$. edulis.

The pulp weight found for fruits from conventional system without grafting was the highest among all, corroborating with the data of fruit weight with a mean of $122.34 \mathrm{~g}$, with an increase of $54.06 \%$, followed by the fruits of organic with grafting and conventional with grafting, with averages of $87.87 \mathrm{~g}$ and $79.41 \mathrm{~g}$, respectively (Table 1). These data corroborate with fruit weight. Thus, it is possible to observe that the fruits of ungrafted plants showed higher production, with fruit weight, longitudinal and transverse length and pulp weight superior. However, pulp yield was lower. Results of Salazar et al. (2015), when evaluated fruits of $P$. edulis grafted on P. gibertii were similar to those of conventional without grafting, with 130.46 g. However, the values of all cultivation systems were lower than those found by Cavichioli et al. (2011a), which studied yellow passion fruits grafted on P. edulis, P. alata and P. gibertii, and ungrafted, with $218.44 \mathrm{~g}, 223.04 \mathrm{~g}, 199.68 \mathrm{~g}$ and $218.00 \mathrm{~g}$, respectively. Statistically, these values did not differ from each other.

For longitudinal and transverse length, the fruits collected from conventional without grafting system stood out in relation to the others due to higher values, while those from organic with grafting and conventional with grafting were the lowest (Table 1). In general, the fruits of grafted plants were smaller than those of ungrafted plants (weight, longitudinal and transverse length). However, they presented higher pulp yield. Cavichioli et al. (2011b), studying yellow passion fruit of grafted and ungrafted plants, evidenced greater fruits in ungrafted plants, 109.1 $\mathrm{mm}$ in longitudinal length and $82.4 \mathrm{~mm}$ in transverse length. Fruits of grafted plants obtained an average of

Table 1: Fruit weight, pulp weight, longitudinal and transverse length of passion fruit in the mature and ripe stages from different cultivation systems. ${ }^{1}$

\begin{tabular}{|c|c|c|c|c|c|c|c|c|c|c|}
\hline \multirow{3}{*}{ Maturation stage } & \multicolumn{10}{|c|}{ Characteristics } \\
\hline & \multicolumn{3}{|c|}{ Fruit weight (g) } & \multirow[t]{2}{*}{ Pulp weight (g) } & \multicolumn{3}{|c|}{ Longitudinal length (mm) } & \multicolumn{3}{|c|}{ Transverse length $(\mathrm{mm})$} \\
\hline & Mature & Ripe & Mean & & Mature & Ripe & Mean & Mature & Ripe & Mean \\
\hline Mature & - & - & - & $91.60^{\mathrm{a}}$ & & & & & & \\
\hline Ripe & - & - & - & $85.52^{b}$ & & & & & & \\
\hline \multicolumn{11}{|l|}{ System } \\
\hline $\begin{array}{l}\text { Conventional without } \\
\text { grafting }\end{array}$ & $315.79^{\mathrm{aA}}$ & $333.77^{\mathrm{aA}}$ & 324.78 & $122.34^{a}$ & $105.97^{\mathrm{aA}}$ & $108.58^{\mathrm{aA}}$ & 107.27 & $90.96^{\mathrm{aA}}$ & $93.92^{\mathrm{aA}}$ & 92.44 \\
\hline Organic with grafting & $184.16^{\mathrm{bA}}$ & $178.83^{\mathrm{bA}}$ & 181.49 & $87.87^{b}$ & $89.64^{\mathrm{bA}}$ & $90.84^{\mathrm{bA}}$ & 90.24 & $78.77^{\mathrm{cA}}$ & $82.61^{\mathrm{bA}}$ & 80.69 \\
\hline Conventional with grafting & $175.88^{\mathrm{bA}}$ & $138.08^{\mathrm{CB}}$ & 156.98 & $79.41^{\mathrm{b}}$ & $94.61^{\mathrm{bA}}$ & $89.49^{\mathrm{bB}}$ & 92.05 & $85.80^{\mathrm{bA}}$ & $81.05^{\mathrm{bB}}$ & 83.42 \\
\hline General Mean & \multicolumn{2}{|c|}{221.08} & \multicolumn{2}{|r|}{96.54} & \multicolumn{2}{|c|}{96.52} & \multicolumn{4}{|c|}{85.51} \\
\hline $\mathrm{CV}(\%)^{2}$ & \multicolumn{2}{|c|}{19.81} & & 27.71 & \multicolumn{2}{|c|}{7.21} & \multicolumn{4}{|c|}{7.74} \\
\hline
\end{tabular}

${ }^{1}$ Means followed by the same capital letter in the line and lower case in the column do not differ, according to the Tukey test at $5 \%$ probability, ${ }^{2}$ Coefficient of variation 
$99.2 \mathrm{~mm}$ in longitudinal length and $80.7 \mathrm{~mm}$ in transverse length. Fruits in the mature and ripe stages of $P$. edulis from conventional with grafting system showed statistically significant differences, where the ripe fruits were smaller than the mature ones. This loss probably occurred due to the wrinkling of the fruits, depreciating the appearance. A higher rate of transpiration at room temperature associated with low relative humidity may have facilitated loss of water to the environment (Chitarra and Chitarra, 2005).

The peel thickness of the fruits from conventional with grafting system stood out with the lowest value in both mature and ripe maturation stage, presenting values of 6.71 and $5.30 \mathrm{~mm}$, respectively (Table 2). Krause et al. (2012) observed, in cultivars of yellow passion fruit, peel thickness between 6.4 and $7.0 \mathrm{~mm}$. Peel thickness is an important factor to be noticed because it is inversely proportional to the juice yield (Ferreira et al., 2010), as seen on this work. The fruits with the lowest peel thickness presented the highest pulp yield.

The pulp yield (Table 2) found in this study was higher than $35 \%$, an essential characteristic for fruits destined to the juice industry (Farias et al., 2005), where the highest values were provided by grafted plants for presenting smaller fruits and consequently smaller longitudinal and transverse length. Cavichioli et al. (2011b) did not evidenced significant differences in pulp yield in fruits from grafted and ungrafted plants. Among the maturation stages, no differences were observed, only among the cultivation systems, where the fruits from conventional without grafting presented lower pulp yield.

In the firmness of the fruits a reduction of the values was observed with the change of the stage of maturation from mature to ripe, with a reduction of $18.15 \%$ (Table 3 ). This is probably due to the action of pectinolytic enzymes present in the cell wall, which has its action intensified during maturation (Liew et al., 2014). Among the cultivation systems, fruits from conventional without grafting, obtained a firmness of $64.66 \mathrm{~N}$, being statistically different from the other fruits. Linares et al. (2013), studying the mechanical characteristics of passion fruit, found the value of $84.3 \mathrm{~N}$ for the ripe stage and $119.3 \mathrm{~N}$ for the mature stage.

In peel color, there was a statistically significant difference between maturation stages and cultivation systems (Table 4). For the values of luminosity and chromaticity, there is an increase with the advance of the maturation, according to the increment of the yellow color. Already for the values of the hue angle there was a reduction, with the change of color to a shade of darker yellow. In all cultivation systems hue angle was located inside the second
Table 2: Pulp thickness and pulp yield of passion fruit in the mature and ripe stages from different cultivation systems ${ }^{1}$

\begin{tabular}{|c|c|c|c|}
\hline \multicolumn{4}{|c|}{ Characteristics } \\
\hline Maturation stage & Peel thic & ess (mm) & Pulp yield (\%) \\
\hline Mature & - & - & $46.83^{a}$ \\
\hline Ripe & - & - & $44.28^{\mathrm{a}}$ \\
\hline Local & Mature & Ripe & \\
\hline $\begin{array}{l}\text { Conventional without } \\
\text { grafting }\end{array}$ & $10.14^{\mathrm{aA}}$ & $9.25^{\mathrm{bA}}$ & $37.92^{b}$ \\
\hline Organic with grafting & $10.03^{\mathrm{aA}}$ & $11.59^{\mathrm{aA}}$ & $48.53^{a}$ \\
\hline $\begin{array}{l}\text { Conventional with } \\
\text { grafting }\end{array}$ & $6.71^{\mathrm{bA}}$ & $5.30^{c A}$ & $50.21^{a}$ \\
\hline General Mean & \multicolumn{2}{|c|}{8.84} & 45.55 \\
\hline $\mathrm{CV}(\%)^{2}$ & \multicolumn{2}{|c|}{30.33} & 19.18 \\
\hline
\end{tabular}

${ }^{1}$ Means followed by the same capital letter in the line and lower case in the column do not differ, according to the Tukey test at $5 \%$ probability, ${ }^{2}$ Coefficient of variation. Table 3: Firmness of passion fruit in the mature and ripe
stages from different cultivation systems ${ }^{1}$

\begin{tabular}{ll}
\hline Maturation stage & Firmness (N) \\
Mature & $60.49 \mathrm{a}$ \\
Ripe & $49.51 \mathrm{~b}$ \\
Local & \\
Conventional without grafting & $64.66 \mathrm{a}$ \\
Organic with grafting & $48.79 \mathrm{~b}$ \\
Conventional with grafting & $51.54 \mathrm{~b}$ \\
General Mean & 55.00 \\
$\mathrm{CV}(\%)^{2}$ & 22.45 \\
\hline
\end{tabular}

${ }^{1}$ Means followed by the same lower case in the column do not differ, according to the Tukey test at $5 \%$ probability. ${ }^{2}$ Coefficient of variation

quadrant $\left(>90^{\circ}\right)$, that is, yellow color, determining greater intensity. Similar values were found by Salazar et al. (2015), with luminosity varying from 70.82 to 71.94 ; chromaticity from 38.88 to 43.15; and hue angle of 97.20 to 100.43 . The increase in yellow color occurs due to the degradation of chlorophyll, while yellow, orange and red pigments belonging to the group of carotenoids are revealed or synthesized. Such pigments are quite common, and their presence is a signal through the consumer and industry evaluate the maturity and quality of the fruits (Freire et al., 2014). The fruits of the conventional with grafting system were highlighted with the highest values of luminosity and chromaticity and conventional without grafting with the values of hue angle.

For pulp color, no significant differences were observed for values of luminosity (Table 5). In chromaticity, there was only difference in the mature stage, where the fruits of the conventional with grafting system presented the lowest value (53.71). The results obtained by this work were superior to those found by Salazar et al. (2015), where the luminosity ranged from 42.04 to 47.66 and the chromaticity ranged from 10.00 to 13.39 . Pulps of the fruits studied demonstrate greater intensity of color. 
In the hue angle of the pulp, the values of all the fruits were located within the first quadrant (from zero to $90^{\circ}$ ), that is, red to yellow color, with values of 75.47 for conventional without grafting and 82.54 to 83.52 for the other cultivation systems, tending to a more yellowish coloration and greater intensity of red. Fruit staining may be a parameter used as an indicator of fruit quality for industrialization, with preference for fruits having a stable yellow-gold color (Maniwara et al., 2014). Salazar et al. (2015) found values of 84.72 to 94.45 for hue angle of the pulp in yellow passion fruits of plants grafted on wild species.

\section{Chemical characteristics}

There was no significant difference for reducing sugars (RS), total soluble sugars (TSS) and titratable acidity (TA) when observed the maturation stages. However, a statistical difference was observed for the cultivation systems for all quality variables. There was also a significant interaction between the analyzed factors (cultivation system and maturation stage) for soluble solids $(p<0.01)$ and for the SS/TA ratio $(\mathrm{p}<0.01)$ (Table 6$)$.

The total soluble solids, reducing sugars and total soluble sugars presented no statistical difference for the maturation stages. For cultivation systems, highest values for these variables were evidenced in organic with grafting, followed by conventional with grafting. Macoris et al. (2011), studying yellow passion fruit from conventional and organic cultivation, found a situation contrary to that evidenced in this study, where fruits from organic cultivation presented total soluble solids, reducing sugars and total sugars lower than those from conventional cultivation. Inferior values for soluble solids were verified by Junqueira et al. (2006), whose results were $10.8^{\circ}$ Brix in ungrafted passion fruit and $11.7^{\circ}$ Brix in fruits of plants grafted on Passiflora nitida. Jiménez et al. (2011), studying yellow passion fruit in different stages of maturation, found for soluble solids the values of 13.5 and $17.4^{\circ}$ Brix in the stages of mature and ripe maturation, respectively.

The $\mathrm{pH}$ increased with the advancement of the maturation stage. This fact can be attributed to the hydrolysis of starch to sugars, according to the behavior of carbohydrates during ripening (Pinzon et al., 2007). Jiménez et al. (2011) found values of 2.45 and 2.77 for yellow passion fruit in different stages of maturation. In relation to cultivation systems, presented a value of 3.26, statistically different from conventional with and without grafting. Macoris et al. (2011) found 3.16 and 3.29 for organic and conventional systems, respectively.

The values of titratable acidity were higher in the fruits from conventional cultivation without grafting, with $4.87 \mathrm{mg} / 100 \mathrm{~g}$. No significant statistical differences were evidenced for the maturation stages. The titratable acidity varies due to the consumption of organic acids during fruit

Table 4: Luminosity, chromaticity and hue angle $\left({ }^{\circ} \mathrm{H}\right)$ of the peel of passion fruit in the mature and ripe stages from different collection sites ${ }^{1}$

\begin{tabular}{|c|c|c|c|c|c|c|}
\hline \multirow{3}{*}{ System } & \multicolumn{6}{|c|}{ Characteristics } \\
\hline & \multicolumn{2}{|c|}{ Peel luminosity } & \multicolumn{2}{|c|}{ Peel chromaticity } & \multicolumn{2}{|c|}{ Peel ${ }^{\circ} \mathbf{H}$} \\
\hline & Mature & Ripe & Mature & Ripe & Mature & Ripe \\
\hline Conventional without grafting & $57.50^{\mathrm{cB}}$ & $73.49^{\mathrm{cA}}$ & $35.51^{\mathrm{bB}}$ & $54.41^{\mathrm{aA}}$ & $109.88^{\mathrm{aA}}$ & $92.29^{\mathrm{aB}}$ \\
\hline Organic with grafting & $71.50^{\mathrm{bB}}$ & $80.46^{\mathrm{bA}}$ & $49.64^{\mathrm{aB}}$ & $55.23^{\mathrm{aA}}$ & $101.48^{\mathrm{bA}}$ & $90.29^{\mathrm{aB}}$ \\
\hline Conventional with grafting & $75.67^{\mathrm{aB}}$ & $84.21^{\mathrm{aA}}$ & $50.25^{\mathrm{aB}}$ & $54.20^{\mathrm{aA}}$ & $99.51^{\mathrm{bA}}$ & $90.59^{\mathrm{aB}}$ \\
\hline General Mean & \multicolumn{2}{|c|}{73.80} & \multicolumn{2}{|c|}{49.87} & \multicolumn{2}{|c|}{97.43} \\
\hline $\mathrm{CV}(\%)^{2}$ & \multicolumn{2}{|c|}{6.25} & \multicolumn{2}{|c|}{12.35} & \multicolumn{2}{|c|}{5.66} \\
\hline
\end{tabular}

${ }^{1}$ Means followed by the same capital letter in the line and lower case in the column do not differ, according to the Tukey test at $5 \%$ probability. ${ }^{2}$ Coefficient of variation.

Table 5: Luminosity, chromaticity and hue angle $\left({ }^{\circ} \mathrm{H}\right)$ of the pulp of passion fruit in the mature and ripe stages from different collection sites ${ }^{1}$

\begin{tabular}{|c|c|c|c|c|}
\hline \multirow{3}{*}{ Maturation stage } & \multicolumn{4}{|c|}{ Characteristics } \\
\hline & \multirow[t]{2}{*}{ Pulp luminosity } & \multicolumn{2}{|c|}{ Pulp chromaticity } & \multirow[t]{2}{*}{ Pulp ${ }^{\circ} \mathrm{H}$} \\
\hline & & Mature & Ripe & \\
\hline Mature & $65.53 \mathrm{a}$ & - & - & $80.72^{\mathrm{a}}$ \\
\hline Ripe & $66.02 \mathrm{a}$ & - & - & $80.31^{a}$ \\
\hline \multicolumn{5}{|l|}{ System } \\
\hline Conventional without grafting & $64.83^{\mathrm{a}}$ & $61.34^{\mathrm{aA}}$ & $61.98^{\mathrm{aA}}$ & $75.47^{b}$ \\
\hline Organic with grafting & $67.02^{\mathrm{a}}$ & $60.82^{\mathrm{aA}}$ & $62.86^{\mathrm{aA}}$ & $82.54^{\mathrm{a}}$ \\
\hline Conventional with grafting & $65.47^{a}$ & $53.71^{\mathrm{bB}}$ & $60.69^{\mathrm{aA}}$ & $83.56^{a}$ \\
\hline General Mean & 65.77 & \multicolumn{2}{|c|}{60.23} & 80.52 \\
\hline $\mathrm{CV}(\%)^{2}$ & 7.00 & \multicolumn{2}{|c|}{9.96} & 6.72 \\
\hline
\end{tabular}

${ }^{1}$ Means followed by the same capital letter in the line and lower case in the column do not differ, according to the Tukey test at $5 \%$ probability. ${ }^{2}$ Coefficient of variation. 
respiration (Pinzón et al., 2007). Moreover, high levels of acids in the juice are important in terms of processing, since it allows greater flexibility in the addition of sugar, when preparing ready-made beverages, besides conferring conditions that hinder deterioration by microorganisms (Flores et al., 2011). Greco et al. (2014) verified in industrialized juices of yellow passion fruit titratable acidity of 2.7 to $3.9 \mathrm{mg} / 100 \mathrm{~g}$, approximate values to those found in this work. Cavichioli et al. (2011b) and Salazar et al. (2015) found that the titratable acidity of fruits of grafted plants did not differ statistically from those of ungrafted plants. However, in this work it was possible to observe that the fruits from conventional cultivation without grafting presented higher acidity.

The SS/TA ratio, in the present work, varied between the cultivation systems and the stages of maturation. The fruits from organic and conventional with grafting stood out with the highest values, due to highest values of total soluble solids, close to those found by Cavichioli et al. (2011a), ranging from 2.8 to 3.5. This relation can be influenced by environmental factors such as sunlight intensity and temperature, type and fertilizer doses
(Nascimento et al., 2003). The analysis of the balance between soluble solids and acids in the fruit has utility in the evaluation of the taste and in the determination of stages of maturation, since its value tends to increase as the fruit reaches the point of harvest (Chitarra and Chitarra, 2005).

\section{Bioactive compounds}

According to the analysis of variance for the bioactive compounds, there was no significant difference for the $\beta$-carotene, total carotenoids and total antioxidant activity by ABTS ( $\mathrm{p}>0.05)$. However, differences were observed for vitamin $\mathrm{C}$ and flavonoids considering the cultivation systems $(\mathrm{p}<0.01)$ (Table 7$)$. There was a significant interaction between the analyzed factors (cultivation system and maturation stage) for total extractable polyphenols $(\mathrm{p}<0.01)$ and for total antioxidant activity by DPPH $(\mathrm{p}<0.05)$ (Table 8).

Among the mature and ripe stages, no statistically significant differences were found for the contents of vitamin $C, \beta$-carotene, total carotenoids, flavonoids and TAA by ABTS method.

Table 6: Total soluble solids (SS), hydrogenation potential (pH), reducing sugars (RS), total soluble sugars (TSS), titratable acidity (TA) and SS/TA ratio of passion fruit in the mature and ripe stages from different cultivation systems ${ }^{1}$

\begin{tabular}{|c|c|c|c|c|c|c|c|c|}
\hline \multirow{3}{*}{ Maturation stage } & \multicolumn{8}{|c|}{ Characteristics } \\
\hline & \multicolumn{2}{|c|}{ SS ( ${ }^{\circ}$ Brix) } & \multirow[t]{2}{*}{$\mathrm{pH}$} & \multirow[t]{2}{*}{ RS (\%) } & \multirow[t]{2}{*}{ TSS (\%) } & \multirow[t]{2}{*}{ TA $(\mathrm{mg} / 100 \mathrm{~g})$} & \multicolumn{2}{|c|}{ SS/TA } \\
\hline & Mature & Ripe & & & & & Mature & Ripe \\
\hline Mature & - & - & $3.14^{b}$ & $4.53^{a}$ & $7.98^{a}$ & $3.86^{a}$ & - & - \\
\hline Ripe & - & - & $3.20^{a}$ & $5.13^{a}$ & $8.03^{a}$ & $4.04^{\mathrm{a}}$ & - & - \\
\hline \multicolumn{9}{|l|}{ System } \\
\hline $\begin{array}{l}\text { Conventional } \\
\text { without grafting }\end{array}$ & $11.16^{\mathrm{CB}}$ & $12.78^{\mathrm{bA}}$ & $3.05^{b}$ & $2.82^{\mathrm{c}}$ & $6.66^{b}$ & $4.87^{\mathrm{a}}$ & $2.30^{\mathrm{cA}}$ & $2.61^{\mathrm{cA}}$ \\
\hline $\begin{array}{l}\text { Organic with } \\
\text { grafting }\end{array}$ & $14.90^{\mathrm{aA}}$ & $14.98^{\mathrm{aA}}$ & $3.26^{\mathrm{a}}$ & $6.99^{a}$ & $9.83^{a}$ & $3.40^{\mathrm{b}}$ & $4.42^{\mathrm{aA}}$ & $4.38^{\mathrm{aA}}$ \\
\hline $\begin{array}{l}\text { Conventional with } \\
\text { grafting }\end{array}$ & $12.98^{\mathrm{bA}}$ & $12.24^{\mathrm{bA}}$ & $3.20^{\mathrm{b}}$ & $4.70^{\mathrm{b}}$ & $7.54^{b}$ & $3.58^{b}$ & $3.86^{\mathrm{bA}}$ & $3.24^{\mathrm{bA}}$ \\
\hline General Mean & \multicolumn{2}{|c|}{13.17} & 3.17 & 4.83 & 8.01 & 3.95 & \multicolumn{2}{|c|}{3.46} \\
\hline $\mathrm{CV}(\%)^{2}$ & \multicolumn{2}{|c|}{7.64} & 1.65 & 18.27 & 13.97 & 6.78 & \multicolumn{2}{|c|}{9.87} \\
\hline
\end{tabular}

${ }^{1}$ Means followed by the same capital letter in the line and lower case in the column do not differ, according to the Tukey test at $5 \%$ probability. ${ }^{2} \mathrm{Coefficient}$ of variation.

Table 7: Vitamin C, $\beta$-carotene, total carotenoids, flavonoids and total antioxidant activity by ABTS method of passion fruit in the mature and ripe stages from different cultivation systems ${ }^{1}$

\begin{tabular}{|c|c|c|c|c|c|}
\hline \multirow{3}{*}{ Maturation stage } & \multicolumn{5}{|c|}{ Characteristics } \\
\hline & Vitamin C & $\beta$-carotene & Total carotenoids & Flavonoids & \multirow{2}{*}{$\begin{array}{c}\text { ABTS } \\
(\mu \mathrm{mol} \text { Trolox } / \mathrm{g})\end{array}$} \\
\hline & \multicolumn{4}{|c|}{$\mathrm{mg} / 100 \mathrm{~g}$} & \\
\hline Mature & $40.75^{\mathrm{a}}$ & $0.20^{\mathrm{a}}$ & $1.15^{\mathrm{a}}$ & $3.82^{\mathrm{a}}$ & $1.82^{\mathrm{a}}$ \\
\hline Ripe & $40.45^{a}$ & $0.20^{\mathrm{a}}$ & $1.17^{\mathrm{a}}$ & $4.49^{\mathrm{a}}$ & $1.78^{\mathrm{a}}$ \\
\hline \multicolumn{6}{|l|}{ System } \\
\hline Conventional without grafting & $43.02^{\mathrm{a}}$ & $0.23^{a}$ & $1.31^{\mathrm{a}}$ & $5.95^{a}$ & $1.81^{\mathrm{a}}$ \\
\hline Organic with grafting & $41.66^{\mathrm{ab}}$ & $0.20^{\mathrm{a}}$ & $1.26^{\mathrm{a}}$ & $3.14^{\mathrm{b}}$ & $1.96^{\mathrm{a}}$ \\
\hline Conventional with grafting & $37.14^{b}$ & $0.18^{a}$ & $0.92^{\mathrm{a}}$ & $3.38^{b}$ & $1.63^{a}$ \\
\hline General Mean & 40.60 & 0.20 & 1.16 & 4.16 & 1.80 \\
\hline $\mathrm{CV}(\%)^{2}$ & 12.72 & 26.01 & 32.28 & 22.50 & 28.01 \\
\hline
\end{tabular}

${ }^{1}$ Means followed by the same lower case in the column do not differ, according to the Tukey test at $5 \%$ probability. ${ }^{2}$ Coefficient of variation. 
Melo, et al.

Table 8: Total extractable polyphenols (TEP) and total antioxidant activity by DPPH method of passion fruit in the mature and ripe stages from different cultivation systems ${ }^{1}$

\begin{tabular}{|c|c|c|c|c|}
\hline \multirow{3}{*}{ System } & \multicolumn{4}{|c|}{ Caracteristics } \\
\hline & \multicolumn{2}{|c|}{ TEP $(\mathrm{mg} / 100 \mathrm{~g})$} & \multicolumn{2}{|c|}{ DPPH (g fruit/g DPPH) } \\
\hline & Mature & Ripe & Mature & Ripe \\
\hline Conventional without grafting & $58.98^{\mathrm{aA}}$ & $63.52^{\mathrm{aA}}$ & $38331.47^{\mathrm{bA}}$ & $34151.10^{\mathrm{bA}}$ \\
\hline Organic with grafting & $52.82^{\mathrm{aB}}$ & $64.91^{\mathrm{aA}}$ & $70496.30^{\mathrm{aA}}$ & $52582.92^{\mathrm{abA}}$ \\
\hline Conventional with grafting & $54.80^{\mathrm{aA}}$ & $46.14^{\mathrm{bA}}$ & $40260.84^{\mathrm{bB}}$ & $61341.31^{\mathrm{aA}}$ \\
\hline General Mean & \multicolumn{2}{|c|}{59.01} & \multicolumn{2}{|c|}{49527.32} \\
\hline $\mathrm{CV}(\%)^{2}$ & \multicolumn{2}{|c|}{12.50} & \multicolumn{2}{|c|}{28.79} \\
\hline
\end{tabular}

${ }^{1}$ Means followed by the same capital letter in the line and lower case in the column do not differ, according to the Tukey test at $5 \%$ probability. ${ }^{2}$ Coefficient of variation.

For vitamin $\mathrm{C}$, the fruits collected from conventional without grafting system, with a value of $43.02 \mathrm{mg} / 100 \mathrm{~g}$, was emphasize in relation to the fruits of organic and conventional with grafting, with values of 41.66 and $37.14 \mathrm{mg} / 100 \mathrm{~g}$, respectively. This difference may have been due to the management used in these commercial areas. These values can be promissory, since in all the fruits contents were obtained above $20 \mathrm{mg} / 100 \mathrm{~g}$, the minimum necessary for the market of yellow passion fruit (Santos et al., 2009). According to Ramful et al. (2011), fruits may be classified according to vitamin $\mathrm{C}$ content in three categories: low (30 mg/100g), medium (30-50 mg/100g) and high $(>50 \mathrm{mg} / 100 \mathrm{~g})$. In this classification, the results of this work are considered medium. Salazar et al. (2016), studying fruits from grafted and ungrafted passion fruit, found values of 29.37 to $36.06 \mathrm{mg} / 100 \mathrm{~g}$, respectively. Pertuzatti et al. (2015) found in passion fruit produced under organic cultivation the value of $230 \mathrm{mg} / 100 \mathrm{~g}$ and $190 \mathrm{mg} / 100 \mathrm{~g}$ in fruits of conventional cultivation, using high-performance liquid chromatography (HPLC). The divergence with the data found in this work may be due to the different methodology used. Macoris et al. (2011) found values of 10.60 and $10.87 \mathrm{mg} / 100 \mathrm{~g}$ in organic and conventional passion fruit pulps, respectively. However, there was no statistical difference.

No statistically significant differences were found in the contents of $\beta$-carotene and total carotenoids among the fruits of the cultivation systems. The $\beta$-carotene content in this work ranged from 0.18 to $0.23 \mathrm{mg} / 100 \mathrm{~g}$. In yellow passion fruit, Reis et al. (2018) found contents of $1.33 \mathrm{mg} / 100 \mathrm{~g}$. Pertuzatti et al. (2015) found the concentrations of $0.056 \mathrm{mg} / 100 \mathrm{~g}$ for fruits from organic cultivation and $0.077 \mathrm{mg} / 100 \mathrm{~g}$ from conventional cultivars. These authors attribute this variation not only to the effect of geographic distance, but also due to the maturation stage of the fruits at the moment of the analysis, crop year, variety and storage conditions. The same may have occurred in this work.

In the present study, the total carotenoid content ranged from 0.92 to $1.31 \mathrm{mg} / 100 \mathrm{~g}$, with no statistically significant effect. The content of $1.78 \mathrm{mg} / 100 \mathrm{~g}$ was demonstrated by Reis et al. (2018) and 13.99 and $25.10 \mathrm{mg} / 100 \mathrm{~g}$ by Pertuzatti et al. (2015) in organic and conventional fruits, respectively. The content of total carotenoids in vegetables cannot be considered an absolute value, and may be affected by several factors. As a result of various functions or properties attributed to carotenoid production, there is a global effort to obtain reliable analytical data that provides deeper demonstration of the development of these compounds. As there are a large number of natural carotenoids, conclusive identification is hampered. Carotenoid composition in fruits is often incomplete or conflicting in the literature (Mercadante et al., 1998).

In the content of flavonoids, no statistically significant difference was observed in the maturation stages. The fruits from conventional without grafting system showed the highest concentration. Zeraik and Yariwake (2010) found the value of $0.167 \mathrm{mg} / 100 \mathrm{~g}$ in fruits of $P$. edulis. The concentration of $16.28 \mathrm{mg} / 100 \mathrm{~g}$ was found by Reis et al. (2018). The results obtained in this work suggest that fruits of P. edulis can be compared with other sources rich in flavonoids, such as orange juice (Reis et al., 2018).

In the antioxidant activity by the ABTS method (Table 7), the fruits from all cultivation systems presented great capacity to neutralize free radicals, with no statistically difference between them. However, superior results were found by Talcott et al. (2003), studying hydrophilic fractions containing polyphenols $(14 \mu \mathrm{mol}$ Trolox/g). In this work, only the pulp of the fruit was used. Reis et al. (2018) detected in yellow passion fruit pulp an antioxidant capacity of $121.9 \mu \mathrm{mol}$ Trolox/g.

The presence of phenolic compounds in yellow passion fruit makes this fruit an excellent candidate to evaluate several effects "in vivo". In Table 8 , it is possible to observe that between the maturation stages, in general, no differences were evidenced, where only in the fruits from organic with grafting system there was an expressive increase of the green to yellow stage. Similarly, among the cultivation systems there was no difference, except for the 
concentration of the yellow fruits from conventional with grafting system, which obtained the lowest value. Rotili et al. (2013), studying yellow passion fruit at different times of storage, found at time 0 the concentration of $20.2 \mathrm{mg} / 100 \mathrm{~g}$ of total extractable polyphenols. Septembre-Malaterre et al. (2016) observed the value of $286.6 \mathrm{mg} / 100 \mathrm{~g}$. The phenolic composition of the fruits is determined by genetic and environmental factors, such as, for example, grafting (Robards et al., 1999). However, it was not possible to observe such differences in this work.

By the DPPH method, it was observed that with the progress of the maturation stage from mature to ripe there is a reduction of the antioxidant capacity of the pulp, in the fruits from conventional with grafting system (Table 8). Regarding to the cultivation systems, in the mature stage, the fruits from conventional with and without grafting obtained the highest activities, while in the ripe stage this was evidenced in conventional without grafting fruits. Septembre-Malaterre et al. (2016) concluded that the highest antioxidant capacity was found in yellow passion fruit pulp (64\% of reduced DPPH) when compared to other fruits, including mango, pineapple and banana. López-Vargas et al. (2013), evaluating the antioxidant capacity by the DPPH method in pulp and seed of yellow passion fruit, concluded that the seeds have higher activity. The antioxidant activity in plants is due to the action of a large variety of antioxidant compounds, which are degraded or synthesized according to the physiological state and levels of abiotic and biotic stresses experienced by the organ (Rotili et al., 2013).

\section{CONCLUSIONS}

The mature and ripe maturation stages showed no significant differences. The fruits of conventional cultivation without grafting showed the best results for the physical characteristics, except for the variable pulp yield, where the fruits from conventional cultivation with grafting stood out. Regarding chemical characteristics, the fruits of organic cultivation with grafting were highlighted in soluble solids, $\mathrm{pH}$, total and reducing sugars and the SS/TA ratio. For bioactive compounds, fruits from conventional cultivation without grafting had higher content of vitamin $\mathrm{C}$, yellow flavonoids, total extractable polyphenols and antioxidant activity by the DPPH method.

\section{Authors' contributions}

Melo N.J.A. conducted the experiment, all analyzes and wrote the first draft of the manuscript. Negreiros A.M.P. and Sarmento J.D.A. assisted in the analysis and statistical evaluation. Morais P.L.D. and Sales Júnior R. guided the first author and reviewed the manuscript.

\section{ACKNOWLEDGMENTS}

This study was financed in part by the Conselho Nacional de Desenvolvimento Científico e Tecnológico (CNPq).

\section{REFERENCES}

Aguiar, R. S., P. V. C. Zaccheo, N. Stenzel, M. Colauto, T. Sera and C. S. V. Neves. 2015. Yield and quality of fruits of hybrids of yellow passion fruit in Northern Paraná. Rev. Bras. Frutic. 37: 130-137.

Alvares, C. A., J. L. Stape, P. C. Sentelhas, J. L. M. Gonçalvesand G. Sparovek. 2014. Köppen's climate classification map for Brazil. Meteorol. Z. 22: 711-728.

AOAC. 2002. Official Methods of Analysis of the Association of Official Analytical Chemistry. Association of Official Analytical Chemistry, Washington, USA.

Atucha, A., B. Emmet and T. L. Bauerle. 2014. Growth rate of fine root systems influences rootstock tolerance to replant disease. Plant Soil. 376: 337-346.

Cavichioli, J. C., L. S. Corrêa, A. C. Boliani and J. C. Oliveira. 2009. Uso de câmara úmida em enxertia hipocotiledonar de maracujazeiro-amarelo sobre três porta-enxertos. Rev. Bras. Frutic. 31: 532-538.

Cavichioli, J. C., L. S. Corrêa, A. C. Boliani and P. C. Santos. 2011a. Características físicas e químicas de frutos de maracujazeiroamarelo enxertado em três porta-enxertos. Rev. Bras. Frutic. 33: 905-914.

Cavichioli, J. C., L. S. Corrêa, M. J. M. Garcia and I. H. Fischer. 2011b. Desenvolvimento, produtividade e sobrevivência de maracujazeiro amarelo enxertado e cultivado em área com histórico de morte prematura de plantas. Rev. Bras. Frutic. 33: 567-574.

Cervi, A. C. 2006. O gênero Passiflora (Passifloraceae) no Brasil, espécies descritas após o ano de 1950. Adumbr. Summae Ed. 15: 1-5.

Chitarra, M. I. F. and A. B. Chitarra. 2005. Pós-colheita de Frutos e Hortaliças: Fisiologia e Manuseio. UFLA, Lavras, Brasil.

Farias, M. A. A., G. A. Faria, M. A. P. Cunha, C. P. Peixoto and J. S. Sousa. 2005. Caracterização física e química de frutos de maracujá amarelo de ciclos de seleção massal estratificada e de populações regionais. Magistra. 17: 83-87.

Ferreira, D. F. 2014. Sisvar: A Guide for its Bootstrap procedures in multiple comparisons. Ciênc. Agrotec. 38: 109-112.

Ferreira, F. M., L. G. Neves, C. H. Bruckner, A. P. Viana, C. D. Cruz and M. A. A. Barelli. 2010. Formação de super-caracteres para seleção de famílias de maracujazeiro amarelo. Acta Sci. Agron. 2: 247-254.

Fischer, I. H., C. J. Bueno, M. J. Garcia and A. M. Almeida. 2010. Reação de maracujazeiro-amarelo ao complexo fusariosenematoide de galha. Acta Sci. Agron. 32: 223-227.

Fischer, I. H., M. C. Arruda, A. M. Almeida, M. J. M. Garcia, E. M. Jeronimo, R. N. Pinotti and R. M. A. Bertani. 2007. Doenças e características físicas e químicas pós-colheita em maracujá amarelo de cultivo convencional e orgânico no centro oeste paulista. Rev. Bras. Frutic. 29: 254-259.

Flores, P. S., D. F. P. Da Silva, C. H. Bruckner, S. P. Oliveira and L. C. C. Salomão. 2011. Caracterização físico-química de frutos de maracujazeiro amarelo provenientes da irradiação com raios gama. Ciênc. Rural. 41: 1903-1906.

Francis, F. J. 1982. Analysis of Anthocyanins. In: P. Markakis Anthocyanins as Food Colors. Academic Press, London, UK. 
Freire, J. S., L. Calvacante, A. M. Rebequi, T. J. Dias, M. A. Brehm and J. B. Santos. 2014. Quality of yellow passion fruit juice with cultivation using different organic sources and saline water. Idesia. 32: 79-87.

González-Gallego, J., M. V. García-Mediavilla, S. Sánchez-Campos and M. J. Tuñón. 2014. Anti-inflammatory and immunomodulatory properties of dietary flavonoids. Polyp. Hum. Health Dis. 1: 435452.

Greco, S. M. L., J. R. Peixoto and L. M. Ferreira. 2014. Avaliação física, físico-química e estimativas de parâmetros genéticos de 32 genótipos de maracujazeiro-azedo cultivados no distrito federal. Biosci. J. 30: 360-370.

Higby, W. K. A. 1962. A simplified method for determination of some the carotenoid distribuition in natural and carotene-fortified Orange juice. J. Food Sci. 27: 42-49.

IBGE. 2017. Produção e Área de Produção de Maracujá: 2017. Available from: http://www.ibge.gov.br. [Last accessed on 2018 Nov 30].

Instituto Adolfo Lutz. 2005. Métodos Físico-Químicos para Análise de Alimentos. Instituto Adolfo Lutz, São Paulo, Brasil.

Jesus, C. A. S., E. V. Carvalho, E. A. Girardi, R. C. C. Rosa and O. N. Jesus. 2018. Fruit quality and production of yellow and sweet passion fruit in Northern state of São Paulo. Rev. Bras. Frutic. 40: 1-7.

Jiménez, A. M., C. A. Sierra, F. J. Rodríguez-Pulido, M. L. González-Miret, F. J. Heredia and C. Osorio. 2011. Physicochemical characterization of gulupa (Passiflora edulis Sims. f. edulis) fruit from Colombia during the ripening. Food Res. Int. 44: 1912-1918.

Junqueira, N. T. V., D. A. C. Lage, M. F. Braga, J. R. Peixoto, T. A. Borges and S. E. M. Andrade. 2006. Reação a doenças e produtividade de um clone de maracujazeiro-azedo propagado por estaquia e enxertia em estacas herbáceas de Passiflora silvestre. Rev. Bras. Frutic. 28: 97-100.

Krause, W., L. G. Neves, A. P. Viana, C. A. T. Araújo and F. G. Faleiro. 2012. Produtividade e qualidade de frutos de cultivares de maracujazeiro-amarelo com ou sem polinização artificial. Pesq. Agropec. Bras. 47: 1737-1742.

Larrauri, J. A., P. Rupérez and F. Saura-Calixto. 1997. Effect of drying temperature on the stabilitity of polyphenols and antioxidant activity of red grape pomace peels. J. Agric. Food Chem. 45: 1390-1393.

Liew, S. Q., N. L. Chin and Y. A. Yusof. 2014. Extraction and characterization of pectin from passion fruit peels. Agric. Agric. Sci. Proc. 2: 231-236.

Linares, J. A., B. Castillo and M. T. Londoño. 2013. Characterization of the mechanical properties of the sweet passion fruit (Passiflora ligularis Juss.). Agron. Colomb. 31: 208-214.

López-Vargas, J. H., J. Fernandez-López, J. A. Pérez-Álvarez and M. Viuda-Martos. 2013. Chemical, physico-chemical, technological, antibacterial and antioxidant properties of dietary fibre powder obtained from yellow passion fruit (Passiflora edulis var. flavicarpa) co-products. Food Res. Int. 51: 756-763.

Macoris, M. S., N. S. Janzantti, D. S. Garruti and M. Monteiro. 2011. Volatile compounds from organic and conventional passion fruit (Passiflora edulis f. flavicarpa) pulp. Ciênc. Tecnol. Aliment. 31: 430-435.

Maniwara, P., K. Nakano, D. Boonyakiat, S. Ohashi, M. Hiroi, T. Tohyama. 2014. The use of visible and near infrared spectroscopy for evaluating passion fruit postharvest quality. J. Food Eng. 143: 33-43.

Mercadante, A. Z., G. Britton and D. B. Rodriguez-Amaya. 1998.
Carotenoids from yellow passion fruit (Passiflora edulis). J. Agric. Food Chem. 46: 4102-4106.

Miller, G. L. 1959. Use of dinitrosalicylic acid reagent for determination of reducing sugars. Anal Chem. 31: 426-428.

Minolta Corp. 2007. Precise Color Communication: Color Control from Feeling to Instrumentation. Minolta Corp. Ltda, Osaka, Japan.

Morais, C. A., V. V. Rosso, D. Estadella and L. P. Pisani. 2016. Anthocyanins as inflammatory modulators and the role of the gut microbiota. J. Nut. Biochem. 33: 1-7.

Nagata, M. and I. Yamashita. 1992. Simple method for simultaneous determination of chlorophyll and carotenoids in tomato fruit. J. Food Sci. Technol. 39: 925-928.

Nascimento, W. M. O., A. T. Tomé, M. S. P. Oliveira, C. H. Müller and J. E. U. Carvalho. 2003. Seleção de progênies de maracujazeiroamarelo (Passiflora edulis f. flavicarpa) quanto à qualidade de frutos. Rev. Bras. Frutic. 25: 186-188.

Nogueira, F. G. C., G. Roncatto, C. Ruggiero, J. C. Oliveira and E. B. Malheiros. 2010. Desenvolvimento e produção das plantas de maracujazeiro-amarelo produzidas por enxertia hipocotiledonar sobre seis porta-enxertos. Rev. Bras. Frutic. 32: 535-543.

Obanda, M. and P. O. Owuor. 1997. Flavonol composition and caffeine content of green leaf as quality potential indicators of Kenyan black teas. J. Sci. Food Agric. 74: 209-215.

Pertuzatti, P. B., M. Sganzerla, A. C. Jacques, M. T. Barcia and R. C. Zambiazi. 2015. Carotenoids, tocopherols and ascorbic acid content in yellow passion fruit (Passiflora edulis) grown under different cultivation systems. J. Food Sci. Technol. 64: 259-263.

Pinzón, I., G. Fisher and G. Corredor. 2007. Determinación de los estados de madurez del fruto de la gulupa (Passiflora edulis Sims). Agron. Colomb. 25: 83-95.

Ramful, D., E. Tarnus, O. I. Aruoma, E. Bourdan and T. Bahorun. 2011. Polyphenol composition, Vitamin C content and antioxidant capacity of Mauritian citrus fruit pulps. Food Res. Int. 44: 20882099.

Re, R., N. Pellegrini, A. Proteggente, A. Pannala, M. Yang and C. Riceevans. 1999. Antioxidant activity applying an improved ABTS radical cation decolorization assay. Free Radic. Biol. Med. 26: 1231-1237.

Reis, L. C. R., E. M. P. Facco, M. Salvador, S. M. Flôres and A. O. Rios. 2018. Antioxidant potencial and physicochemical characterization of yellow, purple and orange passion fruit. J. Food Sci. Technol. 55: 2679-2691.

Robards, K., P. D. Prenzler, G. Tucker, P. Swatsitang and W. Glover. 1999. Phenolic compounds and their role in oxidative processes in fruits. Food Chem. 66: 401-436.

Rotili, M. C. C., S, Coutro, V. M. Celant, J. A. Vorpagel, F. K. Barp, A. B. Salibe and G. C. Braga. 2013. Composição, atividade antioxidante e qualidade do maracujá amarelo durante o armazenamento. Semin. Ciênc. Agrár. 34: 227-240.

Salazar, A. H., D. F. P. Silva and C. H. Bruckner. 2016. Effect of two rootstocks of genus Passiflora L. on the content of antioxidants and fruit quality of yellow passion fruit. Bragantia. 75: 164-172.

Salazar, A. H., D. F. P. Silva, C. S. Sediyama and C. H. Bruckner. 2015. Caracterização física e química de frutos de maracujazeiroamarelo enxertado em espécies silvestres do gênero Passiflora cultivado em ambiente protegido. Rev. Bras. Frutic. 37: 635-643.

Sanchez-Moreno, C., J. A. Larrauri and F. Saura-Calixto. 1998. A procedure to measure the antiradical efficiency of polyphenols. J. Sci. Food Agric. 76: 270-276.

Santos, C. E. M., C. H. Bruckner, C. D. Cruz, D. L. Siqueira and L. D. Pimentel. 2009. Características físicas do maracujá-azedo 
em função do genótipo e massa do fruto. Rev. Bras. Frutic. 31: 1102-1110.

Septembre-Malaterre, A., G. Stanislas, E. Douraguia and M. Gonthier. 2016. Evaluation of nutritional and antioxidant properties of the tropical fruits banana, litchi, mango, papaya, passion fruit and pineapple cultivated in Réunion French Island. Food Chem. 212: 225-233.

Silva, A., E. J. Oliveira, F. Haddad, F. Laranjeira, O. Jesus, S. A. Oliveira, M. A. Carvalho and P. X. Freitas. 2013. Identification of passion fruit genotypes resistant to Fusarium oxysporum f. sp. passiflorae. Trop. Plant Pathol. 38: 236-242.
Strohecker, R. and H. M. Henining. 1967. Análisis de Vitaminas: Métodos Comprobrados. Paz Montalvo, Madrid, Spain.

Talcott, S. T., S. S. Percival, J. Pittet-Moore and C. Celoria. 2003. Phytochemical composition and antioxidant stability of fortified yellow passion fruit (Passiflora edulis). J. Agr. Food Chem. 51: 935-941.

Yemn, E. W. and A. J. Willis. 1954. The estimation of carbohydrate in plant extracts by anthrone. Biochem. J. 57: 508-514.

Zeraik, M. L. and J. H. Yariwake. 2010. Quantification of isoorientin and total flavonoids in Passiflora edulis fruit pulp by HPLC-UV/ DAD. Microchem. J. 96: 86-91. 